\begin{tabular}{|l|l|l||}
\hline \multicolumn{2}{|c|}{ PublisherInfo } \\
\hline \hline PublisherName & $:$ & BioMed Central \\
\hline \hline PublisherLocation & $:$ & London \\
\hline \hline PublisherImprintName & $:$ & BioMed Central \\
\hline \hline
\end{tabular}

\title{
TRANCE/RANKL in bone erosion in arthritis
}

\begin{tabular}{||l|l|l||}
\hline \multicolumn{3}{|c||}{ ArticleInfo } \\
\hline \hline ArticleID & $:$ & 292 \\
\hline \hline ArticleDOI & $:$ & $10.1186 /$ ar-2002-74450 \\
\hline \hline ArticleCitationID & $:$ & 74450 \\
\hline \hline ArticleSequenceNumber & $:$ & 45 \\
\hline \hline ArticleCategory & $:$ & Paper Report \\
\hline \hline ArticleFirstPage & $:$ & 1 \\
\hline \hline ArticleLastPage & $:$ & 3 \\
\hline \hline & & RegistrationDate $: 2002-1-14$ \\
ArticleHistory & $:$ & Received \\
& Accepted 2002-1-14 & $:$ 2002-1-15 \\
& & OnlineDate $\quad 2002-1-21$ \\
\hline \hline ArticleCopyright & $:$ & Biomed Central Ltd2002 \\
\hline \hline ArticleGrants & $:$ & \\
\hline \hline
\end{tabular}




\begin{tabular}{|l|l|l||}
\hline ArticleContext & $:$ & 130754411 \\
\hline
\end{tabular}

Riako Masuda, ${ }^{\text {Affl }}$

Affl Center of Experimental Rheumatology, University Hospital Zurich, Switzerland

\section{Keywords}

Bone erosion, cartilage destruction, osteoclast, serum transfer model, TRANCE/RANKL

\section{Context}

Although joint destruction is a complication of severe rheumatoid arthritis (RA), the definitive pathogenic mechanisms have yet to be elucidated. TRANCE/RANKL has been characterized as an essential factor not only for osteoclastogenesis, but also for the viability of dendritic cells resulting in the activation and proliferation of $\mathrm{T}$ cells. A significant reduction of bone erosion is seen in the adjuvant arthritis model after blockade of TRANCE/RANKL. To exclude the influence of T cell-dendritic cell interactions on this process, the authors generated inflammatory arthritis in TRANCE/RANKL-deficient mice using a serum transfer model bypassing the requirement for $\mathrm{T}$ cell activation.

\section{Significant findings}

Following serum transfer, inflammation developed in TRANCE/RANKL knockout mice similarly to matched littermates; however, bone erosion was dramatically reduced in the knockout mice. In contrast, erosion of cartilage could not be prevented. These results suggest that osteoclasts play a critical role in the pathogenesis of bone erosion in RA independent of T cell-dendritic cell interactions, but that the mechanism of cartilage destruction, as well as the factors which drive the inflammatory process, appears to be different from those of bone erosion.

\section{Comments}


In contrast to this study, protection from cartilage destruction has been previously reported in the adjuvant arthritic model after blockade of TRANCE/RANKL. As discussed by the authors, these differences in protection from cartilage erosion could be explained by the degree of primary cartilage damage intrinsic to these models. In addition, it has to be considered that various cells, such as monocyte/macrophages, T cells, and synovial fibroblasts (SF), may also contribute to joint destruction in

RA. Furthermore, it has been shown that RA-SF can induce osteoclastogenesis by producing TRANCE/ RANKL and can release matrix degrading proteases. Thus, cartilage degradation requires a complex interaction between different cell types. The difference in the protection from cartilage erosion in these models is noteworthy and needs to be examined in more detail.

\section{Methods}

TRANCE/RANKL-deficient mice, serum transfer model of arthritis, micro CT imaging, haematotoxylin and eosin staining, toluidine blue staining, fluorescent staining

\section{Additional information}

Kong YY, Feige U, Sarosi I, Bolon B, Tafuri A, Morony S, Capparelli C, Li J, Elliott R, McCabe S, Wong T, Campagnuolo G, Moran E, Bogoch ER, Van G, Nguyen LT, Ohashi PS, Lacey DL, Fish E, Boyle WJ, Penninger JM: Activated $T$ cells regulate bone loss and joint destruction in adjuvant arthritis through osteoprotegerin ligand. Nature 1999, 402:304-309.

\section{References}

1. Pettit AR, Ji H, Stechow DV, Muller R, Goldring SR, Choi Y, Benoist C, Gravallese EM: TRANCE/ RANKL knockout mice are protected from bone erosion in a serum transfer model of arthritis. Am J of Pathol. 2001, 159: 1689-1699.

This PDF file was created after publication. 